\title{
Paparan Morfin Dosis Letal pada Bangkai Tikus terhadap Pertumbuhan Larva Sarcophaga Sp.
}

\section{The Exposure of Lethal Dose Morphine to Rat Carrion Mouse on the Growth of Fly Bow Sarcophaga Sp.}

\author{
Dicky Faizal I', Aswin Djoko B', Bambang Sidharta ${ }^{3}$ \\ ${ }^{1}$ Program Studi Pendidikan Dokter Fakultas Kedokteran Universitas Brawijaya Malang \\ ${ }^{2}$ Laboratorium Parasitologi Fakultas Kedokteran Universitas Brawijaya Malang \\ ${ }^{3}$ Laboratorium Farmasi Fakultas Kedokteran Universitas Brawijaya Malang
}

\begin{abstract}
ABSTRAK
Dalam mengidentifikasi jenazah yang tidak terdeteksi, peran post mortem interval (PMI) sangat penting untuk memperkirakan waktu kematian dengan menentukan umur larva lalat yang terdapat pada jenazah. Umur larva lalat sangat dipengaruhi oleh suhu lingkungan, makanan, kelembapan, intensitas cahaya, dan kontaminan. Kontaminan yang dapat mempengaruhi pertumbuhan larva lalat adalah narkotika. Keberadaan bahan narkotika mampu mengacaukan estimasi waktu kematian hingga 29 jam. Penelitian ini merupakan penelitian eksperimental menggunakan media dua bangkai tikus tanpa paparan morfin dan dengan paparan morfin dosis letal. Kedua media tumbuh ini dimasukkan kandang dengan lalat Sarcophaga Sp. Dilakukan pengamatan setiap 24 jam mulai dari larva lalat stadium satu sampai lalat dewasa. Dari setiap media tumbuh diambil lima larva secara acak setiap hari, direndam dalam air panas sampai mati. Selama penelitian dilakukan penentuan stadium larva berdasarkan panjangnya dan jumlah slit pada posterior spirakelnya. Hasil menunjukkan pada media tumbuh yang dipapar morfin dosis letal menunjukkan hasil pertumbuhan larva baik panjang maupun berat lebih tinggi secara signifikan dibandingkan pertumbuhan larva pada media tumbuh yang tidak dipapar morfin dosis letal dengan durasi pencapaian stadium lebih cepat. Perbedaan panjang larva dan durasi pencapaian stadium mulai tampak setelah larva stadium satu.
\end{abstract}

Kata Kunci: Entomologi forensik, morfin dosis letal, Sarcophaga Sp.

\begin{abstract}
In predicting the mortality time of unidentified corpse, the role of Post Mortem Interval (PMI) is very important. One of the methods is by determining the age of the larvae in the corpse. The age of the larvae are influenced by environment temperature, food, humidity, light intensity and contaminant. One of the contaminants which affecting flies larvae growth is narcotics. Narcotics can disrupt the mortality time estimation till 29 hours. This is an experimental research using media of rat carrion, one with lethal dose of narcotics and the other one is not. Both media placed in the cage of Sarcophaga Sp flies, and observed every 24 hours from first stadium of larvae to adult stage. Everyday 5 flies were randomly taken from each media, soaked in hot water until death. The larvae stadium determined by measuring its body length and counting the amount of slit on its posterior spiracle. The results showed that larvae from lethal morphine dose exposed media has significantly better development on its length and weight and also faster duration to reach adult stage, compared to the other media (control). The difference of larvae length and duration of the stadium start from first stadium of larvae.
\end{abstract}

Keywords: Forensic entomology, lethal dose morphine, Sarcophaga Sp.

Jurnal Kedokteran Brawijaya, Vol. 26, No. 4, Agustus 2011; Korespondensi: Dicky Faizal I. Program Studi Pendidikan Dokter Fakultas Kedokteran Universitas Brawijaya Malang, Jl. Veteran Malang Tel. (0341) 560491 Email:dr.dicky.faizal@gmail.com 


\section{PENDAHULUAN}

Akhir-akhir ini banyak kematian yang tidak wajar, antara lain disebabkan pembunuhan, pemerkosaan, overdosis obat, keracunan, maupun bunuh diri. Kematian tidak wajar sebagian besar tidak terdeteksi dan ketika ditemukan hanya tertinggal mayat yang mulai membusuk dengan banyak larva lalat di sekujur tubuhnya (1).

Perkembangan larva lalat ketika berhabitat di mayat, baik saat stadium larva maupun saat dewasa, dipengaruhi banyak hal, diantaranya dipengaruhi makanan, musim, suhu lingkungan, panas yang dihasilkan dari pergerakan larva, letak geografis, kontaminan (racun) dan kelembaban $(2,3)$. Keberadaan bahan narkotika mampu mengacaukan estimasi waktu kematian sampai 29 jam (1). Bahan-bahan kimia yangdapat mempercepat atau memperlambat pertumbuhan larva lalat antara lain Triazolam, Oxazepam, Alimemazine, Chloripriamine, Phenobarbital, Malathion, Mercury, Amitriptyline, Nortriptyline, Cocaine, Phenycyclidine, Heroin, serta Morfin (2)

Narkotika di Indonesia merupakan permasalahan yang sangat serius dalam kurun waktu enam tahun terakhir ini. Dalam kurun waktu tersebut, kasus penyalahgunaan narkotika, psikotropika, dan bahan aditif lainnya mengalami angka peningkatan yang sangat drastis yaitu 205\%. Menurut data Badan Narkotika Nasional (BNN) setiap tahun setidaknya 15 ribu orang Indonesia yang banyak didominasi oleh remaja meninggal karena narkoba (4). Karena banyaknya kematian akibat overdosis narkoba, yang sebagian besar terdiri dari morfin, yang terlambat terdeteksi, maka peran Post Mortem Interval (PMI) dalam pengidentifikasian jenazah menjadi sangat penting.

Post Mortem Interval (PMI) adalah waktu dari sejak kematian terjadi pada seorang manusia ataupun hewan sampai ditemukannya jenazah manusia atau hewan tersebut oleh manusiadapat diartikan sebagai perkiraan waktu kematian (5). Data PMI dapat menjadi kunci keberhasilan dalam investigasi kematian, baik yang karena kriminal maupun non-kriminal. Pengetahuan tentang waktu kematian ini sangat berguna untuk menyusutkan tersangka pembunuhan (6). Saat kematian dapat memiliki implikasi yang penting bahkan pada kasus kematian yang normal. Dalam dunia forensik, berbagai cara dapat dilakukan untuk menentukan saat kematian jenazah, antara lain dengan menentukan umur larva lalat yang terdapat pada jenazah, seperti yang dilakukan dalam dunia forensic entomology (7).

Pada kasus-kasus forensik di Malang, penemuan larva insekta mengerucut pada empat spesies dari ordo Diptera, terutama species yang dapat menimbulkan myasis seperti Chrysomia sp, Lucillia sp, Musca sp, dan Sarcophaga sp (data pemeriksaan dari lab. Parasitologi FKUB). Umumnya serangga betina meletakkan telur, atau langsung meletakkan larva pada Sarcophagidae, pada saat beberapa jam setelah kematian. Pertumbuhan lalat tersebut melalui beberapa stadium berikut: telur, larva stadium 1, larva stadium 2, larva stadium 3, prepupa, pupa dengan puparium, imago (5). Sarcophagidae atau yang sering disebut sebagai lalat daging, merupakan kolonisator utama mayat di daerah tropis. Sarcophagidae lebih sedikit menanamkan larvanya di mayat dibandingkan Calliphoridae (1).

\section{METODE}

Penelititan ini merupakan penelitian eksperimental laboratorium untuk mengetahui pengaruh paparan morfin dosis letal pada bangkai tikus terhadap larva Sarcophaga Sp. dengan membandingkan pertumbuhan larva pada bangkai tikus dengan paparan morfin dosis letal dengan pada bangkai tikus tanpa paparan morfin. Populasi yang digunakan adalah larva lalat Sarcophaga Sp.dengan sampel sebesar sepuluh ekor larva Sarcophaga Sp.dari dua kandang yang masing-masing berisi bangkai tikus tanpa morfin dan bangkai tikus dengan morfin. Kriteria pemilihan sampel adalah lima larva terbesar pada kelompok larva dari setiap media tumbuh. Variabel yang diukur dalam penelitian ini adalah panjang larva, berat larva, dan durasi pertumbuhan larva Sarcophaga Sp. pada media tumbuh dengan morfin dosis letal dan tanpa morfin.

Penelitian ini dilaksanakan di Laboratorium Parasitologi Fakultas Kedokteran Universitas Brawijaya pada bulan Desember 2008-Maret 2009. Media tumbuh yang dipakai adalah berupa bangkai tikus Rattus novergicus strain wistar yang mempunyai berat rata-rata 160 gram. Media tumbuh dengan kandungan morfin adalah bangkai tikus Rattus novergicus strain wistar yang mati akibat pemberian morfin 120mg dengan cara disonde (per oral). Media tumbuh tanpa kandungan morfin adalah bangkai tikus Rattus novergicus strain wistar yang mati akibat dislokasi cervical.

Larva lalat diukur panjangnya dengan menggunakan penggaris dalam keadaan hidup, dan ditimbang beratnya dengan menggunakan timbangan analitik dalam keadaan hidup.Larva lalat SarcophagaSp. berwarna putih, bentuk lebih mirip kerucut daripada sosis, diidentifikasi dari pemeriksaan mikroskopis yaitu bentuk spirakel posterior lurus dengan peritrem terbuka. Mulut terletak pada ujung anterior, dan menggunakan kait untuk menempel pada daging mayat. Kait juga digunakan untuk berpindah tempat.

Lima belas ekor lalat Sarcophaga sp yang berhasil ditangkap, dimasukkan ke dalam dua buah kandang yang telah disediakan. Satu kandang diisi dengan satu bangkai tikus yang mati tanpa paparan morfin tetapi dilakukan dislokasi cervikal dan satu kandang yang lain diisi dengan bangkai tikus yang mati dengan paparan morfin dosis letal.

Pada penelitian ini, berat badan tikus sebesar $160 \mathrm{mg}$. Bila LD50 morfin untuk tikus adalah $461 \mathrm{mg} / \mathrm{kg}$ (8), maka morfin dosis letal yang dibutuhkan adalah sebesar 73.76 mg. Dosis yang diberikan sebesar $120 \mathrm{mg}$ sehingga dipastikan tikus mengalami overdosis morfin. Morfin diberikan dengan cara disonde. Morfin tablet $30 \mathrm{mg}$ sejumlah empat tablet dihaluskan dengan mortar. Lalu diberi $2 \mathrm{ml}$ aquades. Hasilnya berupa larutan morfin. Tablet morfin ini dihaluskan dan dijadikan larutan agar proses absorbsi morfin lebih cepat dibandingkan bila tidak dibentuk larutan. Larutan morfin lalu disonde langsung ke lambung tikus dengan spuit.

Pada kedua tikus dibuat irisan pada garis tengah tubuh bagian ventral sepanjang leher sampai dekat anus sampai tampak organ dalam tubuh tikus dan dimasukkan kandang. Kedua kandang diletakkan dalam ruangan dengan suhu berkisar antara $23^{\circ} \mathrm{C}-26^{\circ} \mathrm{C}$. Pemeriksaan posterior spirakel dilaksanakan ketika larva telah cukup besar untuk diiris tipis posterior tubuhnya tanpa menghancurkan tubuhnya, yaitu larva stadium dua. Dengan pemeriksaan setiap hari, maka akan ditemukan fase metamorfosis larva, dengan data kuantitatif berupa panjang larva masing-masing stadium, berat larva mulai larva stadium tiga dan durasi masing-masing stadium. Dilakukan pemeriksaan setiap hari sekitar pukul 05.0007.00 WIB dan 16.00-18.00 WIB. Bila ditemukan larva, 
diambil lima larva dengan ukuran terbesar, dimasukkan ke air panas sampai mati, diukur panjangnya, ditimbang beratnya, dan dicatat waktu pengambilannya. Larva yang tersisa dibiarkan hidup hingga stadium pupa dan menjadi lalat dewasa. Cara untuk mengamati dan menentukan stadium larva dilakukan dengan memasukkan larva dalam air panas sampai mati. Bagian posterior larva diiris tipis untuk dibua sediaan dan diamati dibawah mikroskop. Data-data hasil yang diperoleh dianalisis dengan uji statistik Independent Sample t-test menggunakan fasilitas SPSS 13.0.

\section{HASIL}

\section{Panjang Larva}

Pengamatan panjang larva dilaksanakan mulai dari hari ke (0), yaitu ketika menangkap lalat dan memasukkan ke kandang. Hal ini dikarenakan Sarcophaga Sp. merupakan jenis lalat dengan larvipara sehingga akan langsung melahirkan larva stadium satu pada hari ke-nol. (a) menunjukkan waktu pengambilan larva pada pagi hari, yaitu pada pukul 05.00-07.00. Indeks (b) menunjukkan waktu pengambilan larva pada sore hari, yaitu pada pukul 16.00-18.00. Pengamatan dilaksanakan sampai semua larva menjadi pupa, lalu berkembang menjadi lalat dewasa.

Pada hari ke-0 (hari ketika lalat dimasukkan ke kandang) didapatkan panjang larva stadium satu masih belum berbeda signifikan $(p=1,00)$ antara larva yang tumbuh pada media dengan paparan morfin dosis letal dan tanpa paparan morfin yaitu masing-masing sebesar 1,6 mm. Pada hari ke-1a (pengamatan pagi hari) didapatkan hasil pengukuran larva stadium duapada media tumbuh dengan paparan morfin dosis letal sebesar 2,6 mm, sedangkan pada media tumbuh tanpa paparan morfin sebesar 2,2 $\mathrm{mm}$. Hal ini menunjukkan bahwa rata-rata panjang larva antara kedua media tumbuh belum berbeda secara signifikan $(p=0,242)$. Pada pengamatan sore harinya, yaitu hari ke-1b didapatkan hasil pengukuran larva stadium duapada media tumbuh dengan paparan morfin dosis letal sebesar $2,8 \mathrm{~mm}$, sedangkan pada media tumbuh tanpa paparan morfin sebesar $2,4 \mathrm{~mm}$. Hal ini menunjukkan bahwa rata-rata panjang larva antara kedua media tumbuh belum berbeda secara signifikan $(p=0,486)$.
Pada hari ke-2a didapatkan hasil pengukuran larva stadium tigapada media tumbuh dengan paparan morfin dosis letal sebesar $8,2 \mathrm{~mm}$, sedangkan pada media tumbuh tanpa paparan morfin sebesar 4,2 $\mathrm{mm}$. Hal ini menunjukkan bahwa rata-rata panjang larva antara kedua media tumbuh berbeda secara signifikan $(p=0,000)$.

Pada pengamatan sore harinya, yaitu hari ke-2b didapatkan hasil pengukuran larva stadium tigapada media tumbuh dengan paparan morfin dosis letal sebesar $11,6 \mathrm{~mm}$, sedangkan pada media tumbuh tanpa paparan morfin sebesar 5,2 mm. Hal ini menunjukkan bahwa ratarata panjang larva antara kedua media tumbuh berbeda secara signifikan $(p=0,001)$.

Pada hari ke-3a didapatkan hasil pengukuran larva stadium tigapada media tumbuh dengan paparan morfin dosis letal sebesar 13,2 mm, sedangkan pada media tumbuh tanpa paparan morfin sebesar $10,2 \mathrm{~mm}$. Hal ini menunjukkan bahwa rata-rata panjang larva antara kedua media tumbuh menjadi tidak berbeda secara signifikan $(p=0,088)$. Pada pengamatan sore harinya, yaitu hari ke-3b didapatkan hasil pengukuran larva stadium tigapada media tumbuh dengan paparan morfin dosis letal sebesar $14,6 \mathrm{~mm}$, sedangkan pada media tumbuh tanpa paparan morfin sebesar $12,2 \mathrm{~mm}$. Hal ini menunjukkan bahwa rata-rata panjang larva antara kedua media tumbuh masih tidak berbeda secara signifikan $(p=0,086)$.

Mulai dari pengukuran hari ke-4a (larva stadium tiga) dan seterusnya ternyata didapatkan nilai $p=0,002$ dan $p=0,000$ yang menunjukkan bahwa panjang larva yang tumbuh pada media dengan paparan morfin dosis letal berbeda secara signifikan dibandingkan panjang larva yang tumbuh pada media tanpa paparan morfin. Hal ini juga ditunjukkan dengan panjang larva pada media tumbuh dengan paparan morfin dosis letal dapat mencapai puncak panjang rata-rata $22,4 \mathrm{~mm}$ pada hari ke-6a, sedangkan panjang larva lalat pada media tumbuh tanpa paparan morfin mencapai puncak panjang rata-rata $15,2 \mathrm{~mm}$ pada hari ke-7b. Pada stadium pupa, panjang pupa yang berasal dari larva yang tumbuh pada media dengan paparan morfin dosis letal mencapai $11,8 \mathrm{~mm}$, lebih panjang dibandingkan pupa yang berasal dari larva yang tumbuh pada media tanpa paparan morfin yang hanya mencapai $8,4 \mathrm{~mm}(\mathrm{p}=0,002)$.



Gambar 1. Perkembangan panjang larva lalat Sarcophaga Sp. 


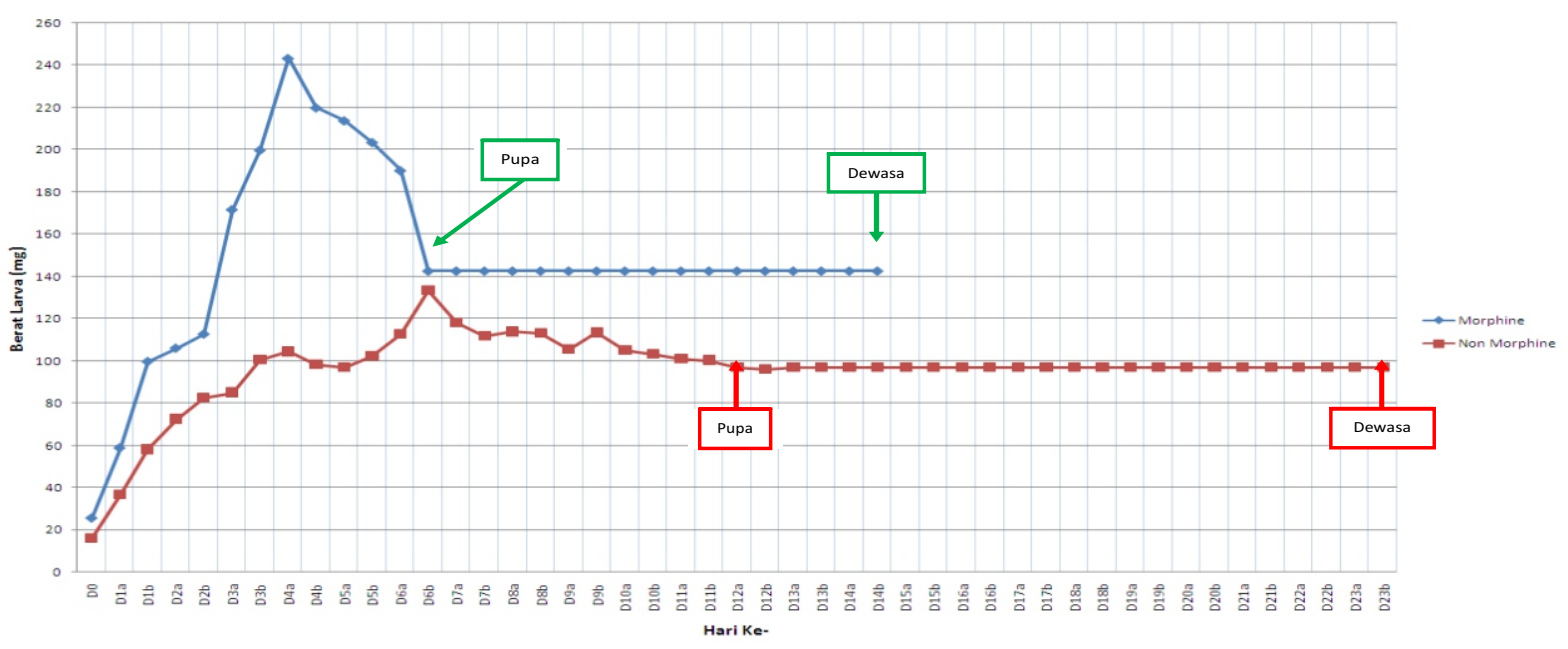

Gambar 2. Grafik berat larva lalat Sarcophaga Sp.

Dapat disimpulkan bahwa keberadaan morfin dalam media hidup lalat secara signifikan mempengaruhi panjang larva lalat, kecuali pada larva stadium satu dan dua. Hal ini mungkin dikarenakan Sarcophaga $S p$. Merupakan jenis lalat larvipara, sehingga tidak bertelur melainkan melahirkan larva. Setelah larva stadium satu mulai makan, sehingga mulai menampakkan efek morfin pada tahap setelah larva stadium dua. Oleh karena itu baru tampak perbedaan yang signifikan pada stadiumstadium berikutnya.

Data menunjukkan bahwa pertumbuhan larva dengan media tumbuh dengan paparan morfin dosis letal mampu mencapai puncak rata-rata panjang $22,4 \mathrm{~mm}$ saat menjadi larva stadium tiga, lalu menjadi pupa dengan panjang rata-rata $11,8 \mathrm{~mm}$. Pertumbuhan larva dengan media tumbuh tanpa paparan morfin (fisiologis), mampu mencapai puncak rata-rata panjang $15,2 \mathrm{~mm}$ saat menjadi larva stadium tiga, lalu menjadi pupa dengan panjang rata-rata $8,4 \mathrm{~mm}$.

\section{Berat Larva}

Pengamatan berat larva dilaksanakan mulai dari hari kedua (2a) pada pagi hari. Hal ini dikarenakan pada hari ke-nol (0) sampai hari ke-satu sore hari (1b), larva masih terlalu kecil untuk dilakukan pengukuran kode (a) menunjukkan waktu pengambilan larva pada pagi hari, yaitu pada pukul 05.00-07.00, sedang (b) menunjukkan waktu pengambilan larva pada sore hari, yaitu pada pukul 16.00-18.00. Pengamatan dilaksanakan sampai semua larva menjadi pupa, lalu berkembang menjadi lalat dewasa.

Data menunjukkan bahwa pertumbuhan larva dengan media tumbuh dengan paparan morfin dosis letal, mampu mencapai puncak rata-rata berat $243,36 \mathrm{mg}$ saat menjadi larva stadium tiga, lalu menjadi pupa dengan berat ratarata $142,8 \mathrm{mg}$. Pertumbuhan larva dengan media tumbuh tanpa paparan morfin (fisiologis), mampu mencapai puncak rata-rata berat $133,2 \mathrm{mg}$ saat menjadi larva stadium tiga, lalu menjadi pupa dengan berat rata-rata $96,78 \mathrm{mg}$.

\section{Durasi Pencapaian Stadium Larva}

Dari pengamatan pencapaian stadium larva, didapatkan data bahwa pada media tumbuh dengan paparan morfin dosis letal pertumbuhan larva dan pencapaian stadium sangat cepat. Setiap stadium larva dapat dicapai dalam satu hari, lalu menjadi pupa hanya dalam tujuh hari setelah peletakan lalat, dan menjadi lalat pada hari ke-15. Pertumbuhan larva dengan media tumbuh tanpa paparan morfin (fisiologis), pencapaian stadium dilalui secara

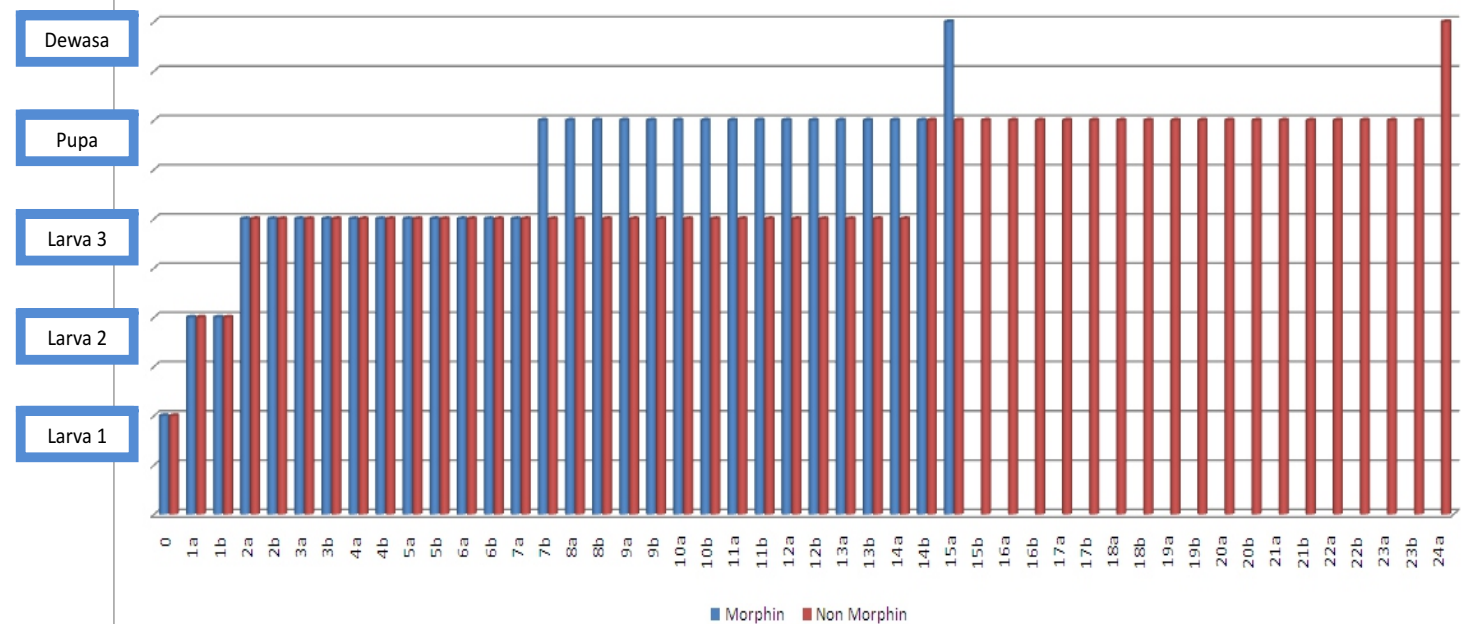

Gambar 2. Grafik berat larva lalat Sarcophaga Sp. 
normal. Pupa terbentuk pada hari ke-14, dan menjadi dewasa pada hari ke-24.

Total durasi yang dibutuhkan mulai dari larva satu hingga menjadi dewasa pada larva yang tumbuh pada media dengan paparan morfin dosis letal yaitu 15 hari. Total durasi yang dibutuhkan mulai dari larva satu hingga menjadi dewasa pada larva yang tumbuh pada media tanpa paparan morfin berlangsung lebih lama yaitu 24 hari.

\section{DISKUSI}

\section{Panjang Larva}

Hasil menunjukkan bahwa keberadaan morfin dalam media hidup lalat mempengaruhi panjang larva lalat Sarcophaga Sp.secara signifikan. Pada hari ke-0 (hari ketika lalat dimasukkan ke kandang) didapatkan panjang larva stadium satu masih belum berbeda signifikan antara larva yang tumbuh pada media dengan paparan morfin dosis letal dan tanpa paparan morfin yaitu masing-masing sebesar 1,6 mm. Hal ini dapat dimengerti karena saat pengukuran hari ke-0 larva tersebut baru saja lahir dan baru mulai makan. Perbedaan juga belum ditemukan pada pengamatan hari ke 1 sore $(p=0,486)$. Pada hari ke-2a didapatkan hasil pengukuran larva stadium tigapada media tumbuh dengan paparan morfin dosis letal lebih panjang secara signifikan $(8,2 \mathrm{~mm}, p<0,001)$ dibandingkan pada media tumbuh tanpa paparan morfin (4,2 mm). Perbedaan signifikan juga ditemukan pada pengamatan hari ke2 sore.

Pada hari ke-3 didapatkan hasil pengukuran larva stadium tigapada kedua media tumbuh tidak menunjukkan perbedaan signifikan. Perbedaan kembali ditemukan sejak hari keempat, panjang larva pada media tumbuh dengan paparan morfin dosis letal dapat mencapai puncak panjang rata-rata $22,4 \mathrm{~mm}$ pada hari ke-6a, sedangkan panjang larva lalat pada media tumbuh tanpa paparan morfin mencapai puncak panjang rata-rata 15,2 $\mathrm{mm}$ pada hari ke-7b. Hal ini mungkin dikarenakan adanya batas berat kritis sehingga pada larva yang tumbuh di media tumbuh dengan morfin memperlambat laju pertumbuhannya pada titik-titik tertentu.

Pada stadium pupa, panjang pupa yang berasal dari larva yang tumbuh pada media dengan paparan morfin dosis letal mencapai $11,8 \mathrm{~mm}$, lebih panjang dibandingkan pupa yang berasal dari larva yang tumbuh pada media tanpa paparan morfin yang hanya mencapai $8,4 \mathrm{~mm}$ $(p=0,002)$. Dapat disimpulkan bahwa keberadaan morfin dalam media hidup lalat secara signifikan mempengaruhi panjang larva lalat, kecuali pada larva stadium satu dan dua. Untuk menjelaskan fenomena ini, perlu dilakukan penelitian lanjutan, karena penelitian ini merupakan penelitian awal. Fenomena ini dapat dikaitkan dengan data terkait Sarcophaga Sp.yang merupakan jenis lalat larvipara, sehingga tidak bertelur melainkan melahirkan larva (9). Setelah larva stadium satu mulai makan, dan mulai menyesuaikan dengan media tumbuh dengan menampakkan efek morfin pada tahap setelah larva stadium dua.

\section{Berat Larva}

Keberadaan morfin dalam media hidup lalat secara signifikan mempengaruhi berat larva lalat Sarcophaga Sp. Pertumbuhan larva lalat pada media dengan paparan morfin dosis letal ternyata mempunyai berat yang lebih berat secara signifikan dibandingkan larva lalat pada media tanpa paparan morfin sejak pengamatan hari ke dua dan seterusnya.

Pernyataan ini diperkuat lagi dengan data berat larva lalat yang tumbuh pada media dengan paparan morfin dosis letal mencapai puncak berat rata-rata $243,36 \mathrm{mg}$ pada hari ke-5b, sedangkan berat larva lalat yang tumbuh pada media tanpa paparan morfin hanya mencapai puncak berat rata-rata $133,20 \mathrm{mg}$ pada hari ke-8a. Pada stadium pupa, ternyata berat pupa yang berasal dari larva yang tumbuh pada media dengan paparan morfin dosis letal mencapai $142,58 \mathrm{mg}$, lebih berat dibandingkan pupa yang berasal dari larva yang tumbuh pada media tanpa paparan morfin yang hanya mencapai $96,78 \mathrm{mg}$. Dapat disimpulkan bahwa keberadaan morfin dalam media hidup lalat secara signifikan mempengaruhi berat larva lalat pada larva stadium ketiga. Untuk berat larva stadium satu dan dua memang tidak dapat dilaksanakan pada penelitian kali ini, karena keterbatasan alat untuk mengambil larva yang sangat kecil sehingga dikhawatirkan dengan alat yang ada, larva akan hancur.

\section{Pencapaian Stadium Larva}

Pertumbuhan larva lalat pada media tumbuh yang diberi paparan morfin dosis letal juga tumbuh dengan durasi yang berbeda secara signifikan dibandingkan larva lalat pada media tumbuh tanpa paparan morfin. Pada larva stadium satu dan larva stadium dua belum terdapat perbedaan durasi waktu antara larva yang tumbuh pada media dengan dan tanpa paparan morfin. Masing-masing stadium pada masing-masing media tumbuh sama durasinya yaitu 24 jam (1 hari).

Durasi larva stadium tiga yang tumbuh pada media dengan paparan morfin dosis letal ternyata lebih cepat yaitu hanya berlangsung 132 jam (5,5 hari), sedangkan dengan durasi larva stadium tiga yang tumbuh pada media tanpa paparan morfin yang berlangsung lebih lambat yaitu 300 jam (12,5 hari). Stadium pupa pada larva lalat pada media tumbuh yang diberi paparan morfin dosis letal dicapai pada hari ke7 dan menjadi lalat pada hari ke-15. Durasi larva lalat pada media tumbuh tanpa paparan morfin, berlangsung lebih lambat. Stadium pupa dicapai pada hari ke-14. Pada stadium pupa juga dipengaruhi oleh perbedaan media tumbuh, dapat dilihat pada durasi waktu pupa untuk dapat menjadi dewasa pada pupa yang berasal dari larva yang tumbuh pada media dengan paparan morfin dosis letal adalah 180 jam (7,5 hari) dan yang berasal dari larva yang tumbuh pada media tanpa paparan morfin adalah 228 jam (9,5 hari).

Total durasi yang dibutuhkan mulai dari larva satu hingga menjadi dewasa pada larva yang tumbuh pada media dengan paparan morfin yaitu 15 hari, sedangkan total durasi yang dibutuhkan mulai dari larva satu hingga menjadi dewasa pada larva yang tumbuh pada media tanpa paparan morfin berlangsung lebih lama yaitu 24 hari. Dapat disimpulkan bahwa keberadaan morfin dalam media hidup lalat secara signifikan mempengaruhi durasi pencapaian stadium larva lalat. Hal ini dapat dikaitkan dengan morfin yang memiliki aksi mirip asetilkolin (10). Efek morfin pada serangga lebih spesifik pada sistem saraf pusat (10). Sistem saraf pusat serangga memiliki kontrol terhadap produksi berbagai macam hormon, diantaranya dua hormon yang memiliki peran penting dalam proses metamorfosis larva, yaitu hormon ecdyson dan hormon juvenile $(11,12)$.

Titer hormon ecdyson dan juvenile berpengaruh terhadap proses metamorfosis larva. Pada proses larval-to-larval 
molt, titer kedua hormon ini tinggi. Sedangkan proses metamorfosis terjadi bila titer hormon ecdyson tinggi dan hormon juvenile rendah $(11,12)$. Dapat ditarik sebuah hipotesis bahwa efek morfin pada aktifitas sistem saraf pusat serangga akan mempengaruhi produksi hormon ecdyson dan juvenile. Hipotesis ini membutuhkan pembuktian melalui penelitian lanjutan untuk lebih

\section{DAFTAR PUSTAKA}

1. Gill GJ. Decomposition And Arthropod Succession On Above Ground Pig Carrion In Rural Manitoba. [Disertasi]. University of Manitoba, Manitoba. 2005.

2. Rahman $\mathrm{P}$, Baskoro AD, Prastowo W. Pengaruh Amitriptyline Dosis Lethal pada Bangkai Tikus Rattus Norvegicus Strain Wistar terhadap Perkembangan Larva Musca Sp. Jurnal Kedokteran Brawijaya. 2010; $26(2)$ : 96-100.

3. HallM and Brandt A. Forensic Entomology. (Online) 2006. http://www.scienceinschool.org /2006/issue2/forensic.

4. SatriyoD. Permasalahan Narkoba di Indonesia dan Penanggulangannya. (Online) 2003. http:// www.solusihukum.com/news/arsip/narkoba.pdf [diakses 30 Nopember 2007].

5. Goff ML. Estimation of the Postmortem Interval Using Arthropoda Development and Successional Patterns. Forensic Science Review. 1993; 5:81-94

6. Anderson GS. The Use of Insects in Death Investigations: An Analysis of Forensic Entomology Cases in British Columbia Over a Five Year Period. Canadian Society of Forensic Sciences. 1995; 28(4): 277-292. memahami efek morfin terhadap aktifitas kedua hormon.

Hasil penelitian ini membuktikan bahwa kandungan morfin dosis letal pada bangkai tikus mempengaruhi panjang, berat dan pertumbuhan stadium larva Sarcophaga Sp. sejak hari ke dua dengan titik kritis pertumbuhan pada hari ke 3 .

7. Wyss C, Chaubert S, and Cherix D. Case StudyDetermining Post Mortem Interval with Four Blowfly Species (Diptera; Calliphoridae): The Importance of Cross Assessment. Proceeding of the European Association for Forensic Entomology Conference. London, March, 29-30, 2003; p. 28.

8. Ramsland K. The Body Farm: Tenesse Anthropology Research Facility. (Online) 2000. http:// www.crimelibrary.com/criminal_mind/forensics/tim e/2.html.

9. Capinera JL. Encyclopedia of Entomology. 4th volume. New York: Springer; 2008; p. 25-27.

10. Ware GW and Whitacre DM. An Introduction to Insecticides. 4th edition. Ohio: MeisterPro Information Resources; 2004.

11. Cheeta S, Schifano F, Oyefeso A, Webb L, and Ghodse AH. Antidepressant-Related Deaths and Antidepressant Prescriptions in England and Wales, 1998-2000. The British Journal of Psychiatry. 2004;184: 41-47.

12. Rahman P, Baskoro AD, dan Prastowo W. Pengaruh Amitriptyline Dosis Lethal pada Bangkai Tikus Rattus Norvegicus strain Wistar terhadap Pertumbuhan Larva Musca Sp. Jurnal Kedokteran Brawijaya. 2010; 26(2): 96-100. 